\title{
HUBUNGAN BERAT BADAN LAHIR DAN PANJANG BADAN LAHIR DENGAN STUNTING PADA BALITA DI KABUPATEN PIDIE
}

\author{
Putri Tamara Dasantos ${ }^{1}$,Herlina Dimiati ${ }^{2}$, Husnah $^{3}$ \\ ${ }^{1}$ Mahasiswa Fakultas Kedokteran Universitas Syiah Kuala Banda Aceh \\ ${ }^{2}$ Staf pengajar Fakultas Kedokteran Universitas Syiah Kuala \\ ${ }^{3}$ Staf pengajar Fakultas Kedokteran Universitas Syiah Kuala \\ Corresponding author : dasantosputritamara@gmail.com
}

\begin{abstract}
Abstrak
Stunting merupakan kondisi balita yang memiliki panjang badan atau tinggi badan kurang dan jika dibandingkan dengan umurnya atau disebut juga kerdil. Stunting merupakan masalah gizi kronik pada balita yang memiliki banyak faktor penyebabnya seperti kondisi sosial ekonomi, gizi ibu saat hamil, panjang badan dan berat badan lahir, kesakitan pada bayi dan kurangnya asupan gizi pada bayi. Stunting harus dicegah karena akan berdampak pada perkembangan fisik dan kognitif kedepannya. Tujuan penelitian adalah untuk mengetahui hubungan berat badan lahir dan panjang badan lahir dengan kejadian stunting di Kabupaten Pidie. Penelitian dilakukan di 10 desa di Kabupaten Pidie pada tanggal 26 Oktober sampai dengan 1 Desember 2019 terhadap 160 balita, terdiri dari 80 kasus dan 80 kontrol dengan desain case control. Metode sampling probability sampling dengan teknik stratified sampling. Berat badan lahir dan panjang badan lahir diperoleh dari buku KIA atau KMS. Stunting diperoleh dari pengukuran tinggi badan balita dan disesuaikan dengan tabel Permenkes. Hasil penelitian ini mayoritas pada usia $25-60$ bulan $(78,8 \%)$ kasus dan $(72,5 \%)$ kontrol, berjenis kelamin laki-laki (50\%) kasus dan (52,5\%) kontrol, pendidikan terakhir ayah yaitu SMA (51,3\%) kasus dan (47,5\%) kontrol, pendidikan terakhir ibu yaitu SMA $(41,3 \%)$ kasus dan $(48,8 \%)$ kontrol, pekerjaan ayah yaitu petani $(53,8 \%)$ kasus dan (55\%) control dan pekerjaan ibu yaitu ibu rumah tangga baik $(73,7 \%)$ kasus dan $(72,4 \%)$ kontrol. Data dianalisa dengan uji Korelasi Spearman. Hasil analisis menunjukkan tidak ada hubungan berat badan lahir $(\mathrm{p}=1,000 ; \mathrm{OR}=1,000)$ dan panjang badan lahir ( $\mathrm{p}=0,227$; OR $=1,645)$ dengan kejadian stunting pada balita di Kabupaten Pidie. Anak dengan panjang badan lahir pendek beresiko 1,645 kali dapat menjadi stunting.
\end{abstract}

Kata Kunci: berat badan lahir, panjang badan lahir, stunting, balita 


\title{
Relationship Between Birth Weight and Birth Length with Stunting in Toddlers at Pidie District
}

\begin{abstract}
Stunting is a condition of a toddler who has less body length or height and when compared to his age or also called dwarf. Stunting is a chronic nutritional problem in infants who have many contributing factors such as socioeconomic conditions, maternal nutrition during pregnancy, length and birth weight, morbidity in infants and lack of nutrition in infants. Stunting must be prevented because it will have an impact on physical and cognitive development going forward. The purpose of this study was to determine the relationship of birth weight and birth length with the incidence of stunting in Pidie District. The study was conducted in 10 villages in Pidie District on October 26 to December 1, 2019 on 160 children under five, consisting of 80 cases and 80 controls with a case control design. The probability sampling method is stratified sampling. Birth weight and birth length are obtained from the MCH or KMS books. Stunting was obtained from toddlers' height measurements and adjusted to Permenkes tables. The results of this study the majority at the age of 25-60 months (78.8\%) cases and $(72.5 \%)$ controls, male sex $(50 \%)$ cases and $(52.5 \%)$ controls, the father's last education namely high school $(51.3 \%)$ cases and $(47.5 \%)$ controls, the last education of mothers is high school $(41.3 \%)$ cases and $(48.8 \%)$ controls, the work of fathers ie farmers $(53.8 \%)$ cases and ( 55\%) control and occupation of the mother is a good housewife $(73.7 \%)$ cases and $(72.4 \%)$ control. Data were analyzed by the Spearman Correlation test. The analysis showed that there was no relationship between birth weight $(\mathrm{p}=1,000 ; \mathrm{OR}=1,000)$ and birth length $(\mathrm{p}=0.227$; OR $=1,645)$ with the incidence of stunting in children under five in Pidie District. Children with short birth weight at risk 1,645 times can become stunted.
\end{abstract}

Keywords: birth weight, body length birth, stunting, Toddler 


\section{PENDAHULAN}

Stunting merupakan kondisi balita yang memiliki panjang badan atau tinggi badan kurang dan jika dibandingkan dengan umurnya atau disebut juga kerdil. Balita stunting merupakan masalah gizi kronik yang memiliki banyak faktor yang menyebabkannya seperti kondisi sosial ekonomi, gizi ibu saat hamil, kesakitan pada bayi dan kurangnya asupan gizi pada bayi. Stunting ini harus dicegah karena akan berdampak pada perkembangan fisik dan kognitif kedepannya. ${ }^{(1)}$ World Health Organization (WHO) menetapkan anak yang dikatakan stunting, jika diukur dengan ketetapan baku panjang atau tinggi badan yang lebih dari minus standar deviasi. ${ }^{(2)}$

Kondisi stunting secara global pada tahun 2017, sekitar 22,2\% (150,8 juta) anak balita di dunia menderita stunting. Angka kejadian ini sudah mengalami penurunan jika dibandingkan dengan angka stunting pada tahun 2000 yaitu 32,6\%. Data tersebut juga menunjukan bahwa setengah dari anak yang mengalami stunting berasal dari Asia (55\%) dan lebih dari sepertiganya (39\%) tinggal di Afrika. Di Asia, dari regional Asia Tenggara proporsi $(25,7 \%)$. Indonesia termasuk negara ketiga dengan prevalensi tertinggi di regional Asia Tenggara atau South-East Asia Regional (SEAR) yaitu sebesar $36,4 \%{ }^{(1)}$

Hasil Riset Kesehatan Dasar (RISKESDAS), di Indonesia tahun 2018, prevalensi balita dengan tinggi badan berdasarkan usia (TB/U) pendek dan sangat pendek adalah sebesar 30,8\% terdiri dari 11,5\% sangat pendek dan 19,3\% pendek. Prevalensi berdasarkan TB/U pendek dan sangat pendek pada balita tahun 2018 paling tinggi di Nusa Tenggara Timur (42,6\%) dan paling rendah di Jakarta (17,7\%). Aceh berada di urutan 3 teratas yang memiliki angka stunting yang tinggi. ${ }^{(3)}$

Data Tim Nasional Percepatan Penanggulangan Kemiskinan (TNP2K), menyatakan bahwa ada 1600 desa dari 160 kabupaten di Indonesia yang menjadi prioritas dalam pencegahan stunting. Aceh memiliki 3 kabupaten stuntin yang termasuk dari 160 kabupaten tersebut, yaitu Aceh Tengah, Pidie dan Aceh Timur. Kabupaten Pidie memiliki 10 desa yang jadi prioritas pencegahan stunting yaitu Desa Ara, Ule Gunong, Mesjid Usi, Campli Usi, Balee Ujong Rimba, Nien, Teungoh Mangki, Peunadok, Meunasah Panah dan Panton Beunot. ${ }^{(4)}$

Stunting memiliki dampak pada anak, baik jangka pendek dan panjang. Dampak jangka pendek dari stunting terdiri dari peningkatan kejadian kesakitan dan kematian, 
perkembangan kognitif, motorik dan verbal pada anak tidak optimal dan peningkatan biaya kesehatan. Dampak jangka panjang dari stunting ialah postur tubuh yang tidak sesuai dengan umur, meningkatnya risiko obesitas dan penyakit lainnya, menurunnya kesehatan reproduksi, kapasitas belajar dan performa yang kurang optimal saat masa sekolah, serta produktivitas dan kapasitas kerja yang tidak optimal. ${ }^{(1)}$

Bayi yang memiliki riwayat berat badan lahir rendah dapat berefek pada perkembangannya yang dapat dilihat dari antropometri. Berat badan lahir biasanya sangat berhubungan dengan kematian janin, neonatal, morbiditas bayi dan anak serta pertumbuhan dan perkembangan selanjutnya. ${ }^{(5)}$ Panjang badan lahir bayi merupakan salah satu faktor risiko stunting pada balita. Panjang badan lahir merupakan salah satu faktor determinan dalam keterlambatan tumbuh kembangnya. ${ }^{(6)}$

Penelitian Arya Krisna et al. (2018) di Bali, bahwa faktor risiko stunting pada anak-anak adalah pendidikan ayah yang rendah, tinggi ibu kurang dari $150 \mathrm{~cm}$, risiko tinggi usia ibu, berat lahir rendah dan panjang lahir rendah menunjukkan adanya hubungan antara bayi berat lahir dan panjang badan lahir terhadap kejadian stunting. ${ }^{(7)}$ Penelitian Mustamin (2018) di Provinsi Sulawesi Selatan, menunjukan adanya hubungan antara tingkat pendidikan Ibu dan pemberian ASI ekslusif dengan kejadian stunting . ${ }^{(8)}$ Penelitian Antun Rahmadi (2016) di Lampung, menunjukan adanya hubungan antara panjang badan lahir terhadap stunting sedangkan berat badan lahir tidak ada berhubungan dengan stunting. ${ }^{(9)}$ Penelitian tentang hubungan berat badan lahir dan panjang badan lahir terhadap kejadian stunting pada balita usia 0-60 bulan belum pernah dilakukan di Aceh. Stunting mempunyai dampak buruk baik jangka pendek dan jangka panjang yang terjadi pada anak. Berdasarkan fakta-fakta yang telah diuraikan di atas, peneliti ingin melakukan penelitian tentang hubungan berat badan lahir dan panjang badan lahir dengan kejadian stunting pada balita usia 0-60 bulan di Kabupaten Pidie.

\section{METODOLOGI PENELITIAN}

Penelitian ini bersifat analitik dengan menggunakan desain case control. Penelitian dilakukan di 10 desa yang terdiri dari Desa Ara, Ule Gunong, Mesjid Usi, Campli Usi, Balee Ujong Rimba, Nien, Teungoh Mangki, Peunadok, Meunasah Panah dan Panton Beunot pada Kabupaten Pidie. Pengambilan data dilakukan pada 26 
Oktober 2019 hingga 1 Desember 2019. Populasi penelitian ini adalah balita yang mengalami stunting di 10 desa Kabupaten Pidie yaitu sebanyak 393 balita dan populasi kontrol pada penelitian ini adalah balita yang tidak stunting di 10 desa Kabupaten Pidie. Pengambilan sampel dilakukan dengan teknik probability sampling dengan metode stratified sampling. Sampel penelitian ini yaitu sebanyak 160 orang. Instrumen yang digunakan dalam penelitian adalah buku KMS atau KIA, Microtoise, Infantometer dan Tabel PERMENKES. Adapun skala ukur yang digunakan untuk berat badan lahir, Panjang badan lahir dan Stunting adalah ordinal. Penelitian ini menggunakan analisis data univariat untuk mendeskripsikan masing-masing variable dan analisis bivariat untuk mencari hubungan berat badan lahir dan panjang badan lahir dengan stunting pada balita menggunakan uji spearman Rank Correlation Test.

\section{HASIL DAN PEMBAHASAN}

Penelitian ini dilakukan di 10 desa yang terdiri dari Desa Ara, Ule Gunong, Mesjid Usi, Campli Usi, Balee Ujong Rimba, Nien, Teungoh Mangki, Peunadok, Meunasah Panah dan Panton Beunot di Kabupaten Pidie pada tanggal 26 Oktober sampai 1 Desember 2019. Pada penelitian ini didapatkan 160 balita yang memenuhi kriteria inklusi menjadi sampel penelitian. Karakteristik responden pada penelitian ini akan memberikan gambaran distribusi frekuensi tentang umur, jenis kelamin, pendidikan terakhir ayah, pendidikan terakhir ibu, pekerjaan ayah dan pekerjaan ibu. Berikut akan disajikan data distribusi karakteristik responden dalam tabel 1.

Tabel 1 Karakteristik Umum Responden

\begin{tabular}{|l|c|c|c|c|}
\hline \multirow{2}{*}{ Variabel } & \multicolumn{2}{c|}{ Kasus } & \multicolumn{2}{c|}{ Kontrol } \\
\cline { 2 - 5 } & $\mathbf{( n )}$ & $\mathbf{( \% )}$ & $\mathbf{( n )}$ & $\mathbf{( \% )}$ \\
\hline \multicolumn{5}{|l|}{} \\
\hline 24 Bulan & 17 & 21,2 & 22 & 27,5 \\
\hline 25-60 Bulan & 63 & 78.8 & 58 & 72,5 \\
\hline Jenis Kelamin & 40 & 50,0 & 42 & 52,5 \\
\hline laki-laki & 40 & 50,0 & 38 & 47,5 \\
\hline Perempuan & 7 & 8,7 & 8 & 10,0 \\
\hline Pendidikan Terakhir Ayah & 23 & 28,7 & 24 & 30,0 \\
\hline SD & 41 & 51,3 & 38 & 47,5 \\
\hline SMP & 9 & 11,3 & 10 & 12,5 \\
\hline SMA & 9 & \multicolumn{2}{l|}{} \\
\hline Perguruan Tinggi &
\end{tabular}




\begin{tabular}{|l|c|c|c|c|}
\hline Pendidikan Terakhir Ibu & 11 & 13,7 & 7 & 8,7 \\
\hline SD & 24 & 30,0 & 26 & 32,5 \\
\hline SMP & 33 & 41,3 & 39 & 48,8 \\
\hline SMA & 12 & 15,0 & 8 & 10,0 \\
\hline Perguruan Tinggi & 43 & 53,8 & 44 & 55,0 \\
\hline Pekerjaan Ayah & 3 & 3,8 & 5 & 6,3 \\
\hline Petani & 2 & 2,4 & 1 & 1,2 \\
\hline Buruh & 6 & 7,5 & 13 & 16,3 \\
\hline Nelayan & 23 & 28,7 & 13 & 16,2 \\
\hline Pedagang & 3 & 3,8 & 4 & 5,0 \\
\hline Wiraswasta & 59 & 73,7 & 58 & 72,4 \\
\hline Pegawai & 59 & 14 & 17,5 \\
\hline Pekerjaan Ibu & 18 & 2 & 2,5 \\
\hline Ibu Rumah Tangga & 2 & 2,5 & 1 & 1,3 \\
\hline Petani & 0 & 0 & 5 & 6,3 \\
\hline Pedagang & 1 & 1.3 & 5 \\
\hline Wiraswasta
\end{tabular}

Keterangan: $\mathrm{n}=$ frekuensi, $\%=$ presentase

Berdasarkan tabel 1 menunjukkan berdasarkan usia balita mayoritas yaitu usia 2560 bulan sebanyak 63 balita stunting ( 78,8\%) dan 58 balita normal (72,5\%), berdasarkan jenis kelamin yaitu laki-laki 40 balita (50,0\%) yang kasus dan 42 balita (52,5\%) yang kontrol, berdasarkan pendidikan terakhir ayah yaitu SMA sebanyak 41 orang $(51,3 \%)$ kasus dan 38 orang $(47,5 \%)$ kontrol, SSberdasarkan pendidikan terakhir ibu yaitu SMA sebanyak 33 orang (41,3\%) kasus dan 39 orang (48,8\%) kontrol, berdasarkan pekerjaan ayah yaitu petani sebanyak 43 orang $(53,8 \%)$ kasus dan 44 orang $(55,0 \%)$ kontrol, dan berdasarkan pekerjaan ibu yaitu ibu rumah tangga sebanyak 59 orang $(73,7 \%)$ kasus dan 58 orang $(72,4 \%)$ kontrol.

Hasil penelitian ini dominan usia anak sebagai kasus dan kontrol adalah 25-60 bulan. Hal ini sesuai dengan Ratih (2014) menyatakan bahwa usia 25-60 bulan termasuk dalam golongan yang rentan terhadap gizi (kelompok yang paling mudah menderita kelainan gizi), sedangkan saat usia 25-60 mereka sedang mengalami proses pertumbuhan yang relatif pesat. ${ }^{(10)}$ Hasil ini sejalan dengan penelitian Iin Ebtanasari (2018) di Desa Ketandan Madiun pada 76 balita yang menunjukkan bahwa rentang usia balita 0-24 bulan sebanyak 23 balita dan usia $25-60$ bulan sebanyak 53 balita. ${ }^{(1)}$ Selain itu juga, stunting baru nampak setelah anak berusia 2 tahun saat masa pertumbuhannya. $^{(12)}$ 
Hasil penelitian ini dominan berjenis kelamin laki-laki. Hal ini sesuai dengan penelitian Dewi Fitria Permatasari (2018) di wilayah kerja Puskesmas Jagir Surabaya yang menunjukan bahwa balita mayoritas berjenis kelamin laki-laki. Perbedaan nilai status gizi balita ini dapat dipengaruhi oleh adanya standar perhitungan TB/U dan dikategorikan berdasarkan jenis kelamin sesuai dengan standar antropometri penilaian status gizi anak. ${ }^{(13)}$ Penelitian Vilda Ana (2018) di Kota Semarang menunjukkan bahwa balita mayoritas laki-laki, beberapa kemungkinan penyebabnya ialah perkembangan motorik kasar anak laki-laki lebih cepat dan membutuhkan energi lebih banyak. ${ }^{(14)}$

Hasil penelitian ini dominan pendidikan terakhir ayahnya adalah SMA. Penelitian ini sejalan dengan Dewi Fitria Permatasari,dkk (2018) di wilayah kerja Puskesmas Jagir Surabaya didapatkan bahwa mayoritas pendidikan ayah tingkat SMA. ${ }^{(13)}$ Berdasarkan Munthofiah (2008), mengatakan bahwa semakin tinggi pendidikan ayah maka kemampuan keluarga untuk membeli makanan dipengaruhi tingkat pendapatan

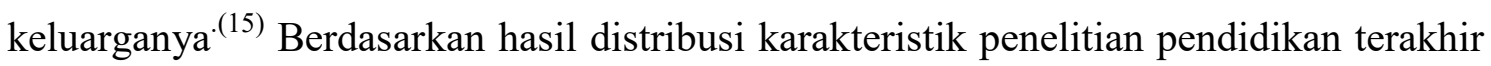
ayah yaitu SMA baik kasus (51,3\%) dan kontrol (47,5\%) memiliki jumlah hampir seimbang. Hal ini sejalan dengan teori ini sehingga kemungkinan pendidikan terakhir ayah ini belum mempengaruhi dalam peningkatan pertumbuhan dan perkembangan anak dalam menerima arahan dan informasi memahami dalam menyediakan gizi seimbang untuk tumbuh kembang anak yang optimal. ${ }^{(16)}$

Hasil penelitian ini dominan pendidikan terakhir ibu adalah SMA. Penelitian ini sejalan dengan Dewi Fitria Permatasari,dkk (2018) di wilayah kerja Puskesmas Jagir Surabaya didapatkan bahwa mayoritas pendidikan ibu tingkat SMA. ${ }^{(13)}$ Tinggi rendahnya pengetahuan ibu berpengaruh terhadap pencapaian status gizi anak dan gizi keluarganya, perilaku hidup sehat, memahami dan menerapkan keluarga berencana. ${ }^{(17)}$ Hasil penelitian didapatkan pendidikan terakhir ibu mayoritas ialah SMA, kemungkinan penyebabnya ibu tidak diterapkan sikap dan pengetahuannya mengenai asupan gizi pada anaknya ataupun tidak optimal.

Hasil penelitian ini dominan pekerjaan ayah adalah petani. Penelitian ini sejalan dengan penelitian dari Christin Debora,dkk (2014) di Biboki Utara Nusa Tenggara Timur didapatkan mayoritas petani ${ }^{(18)}$ Berdasarkan distribusi karakterisktik umum subjek penelitian didapatkan pekerjaan ayah dominan petani. Hal ini sejalan dengan teori yang menjelaskan kemungkinan penyebab status ekonomi keluarga yang rendah 
akan mempengaruhi kualitas maupun kuantitas makanan yang dikonsumsi. Makanan yang didapat kurang bervariasi dan sedikit jumlahnya terutama pada bahan pangan yang berfungsi untuk pertumbuhan anak seperti sumber protein, vitamin dan mineral. ${ }^{(19)}$

Berdasarkan pengamatan peneliti pada saat penelitian, keluarga yang memiliki pendapatan yang rendah sebagian besar memelihara ternak ayam dan bebek serta menanam sayur-sayuran untuk dikonsumsi sendiri. Oleh karena itu, pola asuhan dan asupan gizi yang baik maka gizi anak terpenuhi.

Hasil penelitian ini dominan pekerjaan ibu adalah ibu rumah tangga. Hasil penelitian ini sejalan dengan Atikah Rahayu,dkk (2014) di Banjarmasin didapatkan bahwa mayoritas pekerjaan ibu yaitu ibu rumah tangga sebanyak 48 orang. ${ }^{(20)}$ Berdasarkan hasil penelitian ini dominan pekerjaan ibu ialah ibu rumah tangga. Hal ini sesuai dengan teori yang menjelaskan bahwa kemungkinan penyebabnya pola asuh dan pengetahuan gizi terhadap anak nya tidak baik. ${ }^{(21)}$

Tabel 2 Tabel Data Antropometri

\begin{tabular}{|c|c|c|c|c|}
\hline \multirow{2}{*}{ Variabel } & \multicolumn{2}{|c|}{ Kasus } & \multicolumn{2}{|c|}{ Kontrol } \\
\hline & $\mathbf{n}$ & $\%$ & $\mathbf{n}$ & $\%$ \\
\hline \multicolumn{5}{|l|}{ Berat Badan Lahir } \\
\hline Rendah & 2 & 2,5 & 2 & 2,5 \\
\hline Normal & 78 & 97,5 & 78 & 97,5 \\
\hline \multicolumn{5}{|l|}{ Panjang Badan Lahir } \\
\hline Pendek & 18 & 22.5 & 12 & 15,0 \\
\hline Normal & 62 & 77,5 & 68 & 85 \\
\hline \multicolumn{5}{|l|}{ Stunting } \\
\hline Sangat Pendek & 12 & 15,0 & 0 & 0 \\
\hline Pendek & 68 & 85,0 & 0 & 0 \\
\hline Normal & 0 & 0 & 80 & 100 \\
\hline
\end{tabular}

Keterangan: $\mathrm{n}=$ frekuensi, $\%=$ presentase

Tabel 2 diatas menunjukkan distribusi berat badan lahir menunjukkan bahwa berat badan lahir kelompok kasus memiliki berat badan lahir normal yaitu 78 balita $(97,5 \%)$ sedangkan kelompok kontrol yang berat badan normal yaitu 78 balita $(97,5 \%)$.

Berdasarkan tabel 2 menunjukkan panjang badan lahir kelompok kasus yang memiliki panjang badan lahir pendek yaitu 18 balita (22,5\%) sedangkan kelompok kontrol panjang badan pendek yaitu 12 balita $(15,0 \%)$. 
Berdasarkan tabel 2 menunjukkan bahwa mayoritas balita yang stunting yaitu sangat pendek 12 balita $(15,0 \%)$, pendek 68 balita $(85,0 \%)$ dan semua kontrol yaitu normal sebanyak 80 balita $(100 \%)$.

Tabel 3 Hubungan Berat Badan Lahir dengan Kejadian Stunting

\begin{tabular}{ccccccccc}
\hline & \multicolumn{8}{c}{ Stunting } \\
\cline { 2 - 7 } Berat Badan Lahir & \multicolumn{2}{c}{ Ya } & \multicolumn{2}{c}{ Tidak } & \multicolumn{2}{c}{ Total } & rs \\
\cline { 2 - 7 } & $\mathbf{n}$ & $\%$ & $\mathbf{n}$ & $\%$ & $\mathbf{n}$ & $\%$ & P Value \\
\hline Rendah & 2 & $; 0$ & 2 & 50 & 4 & 100 & 0,000 \\
Normal & 78 & $; 0$ & 78 & 50 & 156 & 100 & 1,000 \\
\hline
\end{tabular}

Keterangan: $\mathrm{n}=$ frekuensi, $\%=$ presentase

Berdasarkan tabel 3 didapatkan balita dengan berat badan lahir rendah stunting sebanyak 2 balita (50\%) dan tidak stunting sebanyak 2 balita (50\%). Balita dengan berat badan lahir normal memiliki risiko stunting 78 balita (50\%) dan tidak stunting sebanyak 78 balita (50\%). Hasil uji statistik dengan uji Spearman Correlation menunjukkan $\mathrm{p}$ value sebesar 1,000 ( $\mathrm{p}$ value $>0,05$ ), yang berarti tidak terdapat hubungan antara berat badan lahir dengan stunting. Nilai Coefficient Correlation (rs) didapatkan sebesar 0,000 yang menunjukkan tidak ada korelasi.

Tabel 4 Odds Ratio berat badan lahir dengan kejadian stunting

\begin{tabular}{ccc}
\hline \multirow{2}{*}{ Berat Badan Lahir } & \multicolumn{2}{c}{ Stunting } \\
\cline { 2 - 3 } & Ya & Tidak \\
\hline Rendah & 2 & 2 \\
Normal & 78 & 78 \\
\hline
\end{tabular}

Rumus Odds Ratio $=\frac{a d}{b c}=\frac{2 \times 78}{2 \times 78}=1$

Berdasarkan tabel 4 didapatkan odds ratio berat badan lahir dengan kejadian stunting didapatkan 1 yang berarti bahwa berat badan lahir rendah berisiko 1 kali menyebabkan stunting. 
Hasil penelitian ini sejalan dengan penelitian Antun Rahmadi (2015) pada 3.129 balita di Provinsi Lampung menunjukkan berat badan lahir tidak ada hubungan dengan stunting dengan P value 0,966 $(\mathrm{p}>0,05) .{ }^{(9)}$ Penelitian ini sejalan dengan Syifa Vaozia (2016) pada 72 balita di Desa Menduran Kecamatan Brati Kabupaten Grobogan, Jawa Tengah menunjukkan berat badan lahir tidak ada hubungan dengan stunting dengan $p$ value $0,500(\mathrm{p}>0,05)^{\cdot(22)}$ Penelitian ini juga sejalan dengan Mentari Irma Diafrilia (2014) wilayah kerja Puskesmas Ranomuut Kecamatan Paldua menunjukkan bahwa berat badan lahir tidak ada hubungan dengan stunting dengan $\mathrm{p}$ value 0,410 ( $\mathrm{p}$ $>0,005){ }^{(23)}$

Hasil penelitian ini tidak sejalan dengan penelitian yang dilakukan oleh Dandara Swathma,dkk (2016) pada 102 orang Wilayah Kerja Puskesmas Kandai Kota Kendari menunjukkan bahwa terdapat hubungan antara berat badan lahir dengan nilai $\mathrm{p}$ value $0,002(\mathrm{p}<0,05) .{ }^{(24)}$ Hasil penelitian Atikah Rahayu,dkk (2014) pada 117 orang di Kabupaten Hulu Sungai Utara menunjukan bahwa terdapat hubungan antara berat badan lahir dengan stunting dengan nilai $\mathrm{p}=0,015(\mathrm{p}<0,05) .{ }^{(5)}$

Berat badan lahir tidak terdapat hubungan dengan stunting dikarenakan pengaruh berat badan lahir terjadi pada 6 bulan pertama kehidupan, selanjutnya menurun sampai usia 24 bulan. Dengan demikian jika bayi dapat mengejar pertumbuhan mereka dalam 6 bulan pertama kehidupan maka ada kemungkinan besar untuk mencapai tinggi badan normal. ${ }^{(25)}$ Ketidakcukupan asupan zat gizi yang diterima anak dengan berat lahir normal dapat mengakibatkan growth faltering. Asupan gizi buruk dan paparan penyakit infeksi secara bersamaan akan memberikan dampak gagal tumbuh yang lebih berat pada anak dengan berat lahir normal. Jika anak dengan berat badan lahir rendah menerima asupan gizi yang adekuat maka pertumbuhan normal dapat terkejar (catch up). Riwayat BBLR tidak mempengaruhi pertumbuhan anak apabila anak mendapatkan asupan yang cukup dan kondisi lingkungan yang mendukung pertumbuhan dan perkembangan anak. $^{(25)}$

Balita yang memiliki berat badan lahir normal, tetapi stunting $(97,5 \%)$ memiliki tingkat konsumsi energi yang defisit dan memiliki riwayat penyakit infeksi kronis. Apabila konsumsi energi tidak mencukupi kebutuhan untuk mempertahankan metabolisme maka pemenuhan kecukupan energi diperoleh dari cadangan lemak dan glikogen otot. Apabila keadaan ini berlangsung dalam jangka waktu lama akan terjadi 
katabolisme guna memenuhi kebutuhan energi sehingga dampak yang ditimbulkan dari konsumsi energi yang kurang adalah terjadinya gangguan pertumbuhan pada anak sehingga anak mengalami stunting. ${ }^{(26)}$

Berdasarkan pengamatan peneliti pada saat penelitian dan wawancara dengan kader di setiap desa, bahwa ibu hamil rutin melakukan pemeriksaan kehamilan dan adanya kelas ibu hamil di posyandu untuk dilakukan penyuluhan. Selain itu, dikarenakan pidie menjadi salah satu target penurunan angka stunting di aceh sehingga seluruh elemen baik masyarakat dan pemerintah ikut serta dalam penurunan angka stunting.

Tabel 5 Hubungan panjang badan lahir dengan kejadian stunting

\begin{tabular}{|c|c|c|c|c|c|c|c|}
\hline \multirow{3}{*}{$\begin{array}{c}\text { Panjang } \\
\text { Badan Lahir }\end{array}$} & \multicolumn{7}{|c|}{ Stunting } \\
\hline & \multicolumn{2}{|c|}{$\mathbf{Y a}$} & \multicolumn{2}{|c|}{ Tidak } & \multicolumn{2}{|c|}{ Total } & \multirow{2}{*}{$\begin{array}{c}\text { rs } \\
\text { P Value }\end{array}$} \\
\hline & $\mathbf{n}$ & $\%$ & $\mathbf{n}$ & $\%$ & $\mathbf{n}$ & $\%$ & \\
\hline Pendek & 18 & 60 & 12 & 40 & 30 & 100 & 0,096 \\
\hline Normal & 62 & 47,7 & 68 & 52,3 & 130 & 100 & 0,227 \\
\hline
\end{tabular}

Keterangan: $\mathrm{n}=$ frekuensi, $\%=$ presentase

Berdasarkan tabel 5 didapatkan balita dengan panjang badan lahir pendek mengalami stunting sebanyak 18 balita (60\%) dan normal sebanyak 12 balita $(40 \%)$. Balita dengan panjang badan lahir normal memiliki risiko stunting sebanyak 62 balita $(47,7 \%)$ dan tidak stunting sebanyak 68 balita (52,3\%). Hasil uji statistik dengan uji Spearman Correlation menunjukkan $\mathrm{p}$ value sebesar 0,227 ( $\mathrm{p}$ value $>0,05$ ), yang berarti bahwa tidak terdapat hubungan panjang badan lahir dengan stunting. Nilai Coefficient Correlation (rs) didapatkan sebesar 0,096 yang menunjukkan tidak ada korelasi.

Tabel 6 Odds Ratio panjang badan lahir dengan kejadian stunting

\begin{tabular}{|l|c|c|}
\hline \multirow{2}{*}{$\begin{array}{l}\text { Panjang } \\
\text { Badan Lahir }\end{array}$} & \multicolumn{2}{|c|}{ Stunting } \\
\cline { 2 - 3 } & Ya & Tidak \\
\hline Pendek & 18 & 68 \\
\hline Normal & 62 & 12 \\
\hline
\end{tabular}


Rumus Odds Ratio $=\frac{a d}{b c}=\frac{18 \times 68}{12 \times 62}=1,645$

Berdasarkan tabel 6 didapatkan odds ratio panjang badan lahir dengan kejadian stunting didapatkan 1,645 yang berarti bahwa bayi pendek berisiko 1,65 kali lebih menyebabkan stunting daripada bayi panjang lahir normal.

Hasil penelitian ini sejalan dengan penelitian Erni Rukmana, (2016) pada 360 balita di wilayah Kota Bogor menunjukkan panjang badan lahir tidak ada hubungan dengan stunting dengan $\mathrm{P}$ value $0,707(\mathrm{p}>0,05) .{ }^{(27)}$ Hasil penelitian ini sejalan dengan penelitian Devy Aulia Juniar, (2018) pada 46 balita di wilayah kerja Puskesmas Gebang, Kecamatan Gebang, Kabupaten Purworejo menunjukkan panjang badan lahir tidak ada hubungan dengan stunting dengan $P$ value $0.226(\mathrm{p}>0,05){ }^{(28)}$

Hasil penelitian ini tidak sejalan dengan penelitian yang dilakukan oleh Dewi Fitria Permatasari dan Sri Sumarmi (2018) pada 68 balita Wilayah Kerja Puskesmas Jagir Surbaya menunjukkan bahwa terdapat hubungan antara panjang badan lahir dengan nilai $p$ value $0,03(p<0,05)$. ${ }^{(13)}$

Panjang lahir menggambarkan pertumbuhan linier bayi selama dalam kandungan. Penentuan asupan yang baik sangat penting untuk mengejar masa pertumbuhan anak terutama usia 2-3 tahun akan mengurangi prevalensi terhambatnya pertumbuhan pada anak-anak. Pola asuh ibu yang baik terhadap anaknya merupakan poin penting dalam proses pertumbuhan dan perkembangan anak. ${ }^{(21)}$ Anak dengan panjang lahir menjadi fokus perhatian ibu dalam pemberian asupan gizi dan pola asuh yang baik selama proses pertumbuhan dan perkembangan anak sehingga anak dapat mengejar masa pertumbuhan yang tertinggal. ${ }^{(20)}$

Tinggi badan ibu merupakan salah satu pengaruh pada proses pertumbuhan anak selama 4 periode yaitu masa intrauterin, bayi lahir sampai usia 2 tahun, usia 2 tahun sampai pertengahan masa kanak-kanak dan usia dewasa. Namun ada kemungkinan pengaruh faktor genetik dan non-genetik, termasuk gizi selama masa kehamilan. ${ }^{(29)}$ Hal ini berkaitan dengan penelitian yang dilakukan oleh Zilda et al, menyatakan bahwa ibu yang memiliki tinggi badan pendek mempunyai risiko 1,36 kali memiliki balita stunting dibandingkan dengan ibu yang memiliki tinggi badan normal. ${ }^{(30)}$ Pertumbuhan janin yang kurang memadai selama dalam kandungan berdampak pada pertumbuhan dan 
perkembangan anak selanjutnya. Status gizi yang buruk dan tinggi badan ibu yang pendek dapat meningkatkan risiko kegagalan pertumbuhan di dalam rahim. ${ }^{(31)} \mathrm{Hal}$ ini sejalan dengan penelitian ini yang dimana tinggi badan orang tua pada balita memenuhi kriteria eksklusi artinya tinggi badan orang tua diatas $150 \mathrm{~cm}$, Sehingga didapatkan tidak ada hubungan antara panjang badan lahir dengan stunting.

Bayi yang lahir pendek dapat dipengaruhi oleh beberapa faktor seperti retardasi pertumbuhan atau pertumbuhan yang terhambat saat masih dalam kandungan yang disebabkan oleh kemiskinan, penyakit, dan defisiensi zat gizi yang diderita oleh ibu hamil semenjak trimester awal sampai akhir kehamilan. Tidak adanya hubungan antara berat badan lahir bayi dan panjang badan lahir bayi dapat dipengaruhi oleh faktor lain, seperti sudah terpenuhinya zat gizi bayi. Kecukupan zat gizi perorangan berbeda tergantung pada umur, aktivitas, ukuran tubuh, keadaan fisiologis, derajat pertumbuhan, dan kebutuhan energi ${ }^{(32)}$

Panjang badan lahir didapatkan tidak ada hubungan dengan stunting karena balita di pidie tiap bulan nya melakukan pemantauan status gizi yang dilakukan di posyandu sehingga orang tua mendapatkan penyuluhan kesehatan, pelayanan kesehatan dasar dan penimbangan rutin sehingga anak dapat terhindar dari permasalahan gizi. Berdasarkan pengematan peneliti selama penelitian mendapatkan salah satu desa yakni desa Ara, Kecamatan Kembang Tanjong memiliki Rumoh Gizi tujuan nya untuk tempat sarana pendukung penguatan ketahanan pangan keluarga dan pemberdayaan masyarakat sehingga berhasil menurunkan angka stunting di desa tersebut.

\section{KESIMPULAN}

Berdasarkan hasil penelitian dan pembahasan didapatkan kesimpulan:

1. Tidak terdapat hubungan berat badan lahir dengan stunting pada balita di 10 desa Kabupaten Pidie.

2. Tidak terdapat hubungan panjang badan lahir dengan stunting pada balita di 10 desa Kabupaten Pidie.

\section{Referensi}

1. Departemen Kesehatan Republik Indonesia. Buletin Jendela Data dan Informasi Kesehatan Stunting Di Indonesia. Satriani E, editor. Vol. 1, Kementerian 
Kesehatan RI. Jakarta: Pusat Data dan Informasi; 2018.

2. World Health Organization. Stunting in a nutshell [Internet]. who. [cited 2019 Jun 7]. Available from: https://www.who.int/nutrition/healthygrowthproj_stunted_videos/en/

3. Riskesdas. HASIL UTAMA RISKESDAS 2018 Kementerian Kesehatan [Internet]. 2018. Available from: www.depkes.go.id/resources/download/info...2018/Hasil Riskesdas 2018.pdf $\% 0 \mathrm{~A} \% 0 \mathrm{~A}$

4. Tim Nasional Percepatan Penanggulangan Kemiskinan. Daftar Wilayah Prioritas Tahap 2 / 2018 ( 160 Kabupaten / Kota Prioritas ). Jakarta; 2018.

5. Rahayu, A., Yulidasari, F., Putri, A. O., \& Rahman F. Riwayat Berat Badan Lahir dengan Kejadian Stunting pada Anak Usia Bawah Dua Tahun Birth Weight Records with Stunting Incidence among Children under Two. 2015;6773.

6. Supariasa, Bakri.B \& Fajar I. Penilaian Status Gizi. Jakarta: EGC; 2012.

7. Manggala AK, Wiswa K, Kenwa M, Me M, Kenwa L, Agung A, et al. Paediatrica Indonesiana. 2018;58(5):205-12.

8. Mustamin, Asbar Ramlan B. Hubungan Tingkat Pendidikan Ibu Dan Pemberian Asi Eksklusif Dengan Kejadian Stunting Pada Balita Di Provinsi Sulawesi Selatan Tahun 2015. 2018;25:25-32. Available from: https://www.researchgate.net/publication/327505029_Hubungan_Tingkat_Pendi dikan_Ibu_Dan_Pemberian_Asi_Eksklusif_Dengan_Kejadian_Stunting_Pada_B alita_Di_Provinsi_Sulawesi_Selatan_Tahun_2015

9. Rahmadi A. Hubungan Berat Badan Dan Panjang Badan Lahir Dengan Kejadian Stunting Anak 12-59 Bulan Di Provinsi Lampung. J Keperawatan. 2016;XII(2):209-18.

10. Ibrahim IA, Faramita R. Al - Sihah : Public Health Science Journal Hubungan Faktor Sosial Ekonomi Keluarga dengan Kejadian Stunting Anak Usia 24 - 59 Bulan di Wilayah Kerja Puskesmas Barombong Kota Makassar Tahun 2014. 2015;7:63-75.

11. Ebtanasari I. Hubungan Berat Badan Lahir Rendah dengan Kejadian Stunting Pada Anak Usia 5 Tahun di Desa Ketandan Kabupaten Madiun. 2018;

12. Kementerian Desa Pembangunan Daerah Tertinggal dan Transmigrasi. Buku saku desa dalam penanganan stunting. Buku Saku Desa Dalam Penanganan Stunting. 2017;2-13.

13. Permatasari, Dewi Fitria SS. Perbedaan Panjang Badan Lahir, Riwayat Penyakit Infeksi, dan Perkembangan Balita Stunting dan Non Stunting. J Berk Epidemiol. 2018;6:182-91.

14. Ana V, Setyawati V. Kajian Stunting Berdasarkan Umur dan Jenis Kelamin Di Kota Semarang. 2018;834-8.

15. Munthofiah S. Hubungan antara pengetahuan, sikap, dan perilaku ibu dengan status gizi anak balita. Universitas Sebelas Maret; 2008.

16. Woldehanna, T., Behrman, J. R., \& Araya MW. The effect of early childhood stunting on children's cognitive achievements: evidence from young lives Ethiopia. Ethiop J Heal Dev. 2017;2:75-84.

17. Cruz, L. M. G., Azpeitia, G. G., Suarez, D. R., Rodriguez, A. S. et al. Factors associated with stunting among children aged 0 to 59 months from the Central Region of Mozambique. Nutrients. 2017;9(491):1-16. 
18. Nabuasa CD, Huriyati E. Riwayat pola asuh, pola makan, asupan zat gizi berhubungan dengan stunting pada anak 24 - 59 bulan di Biboki Utara, Timor Tengah Utara, Nusa Tenggara Timur. Gizi dan Diet Indones. 2014;1(1).

19. Kusumawati E, Rahardjo S SH. Model pengendalian faktor risiko stunting pada anak bawah tiga tahun. J Kesehat Masy Nas. 2015;9(3).

20. Rahayu Atikah, Khairiyati L. Risiko pendidikan ibu terhadap kejadan stunting. 2014;37:129-36.

21. Septiana,R, Djannah, R.S.N DM. Hubungan Antara Pola Pemberian Makanan Pendamping ASI dan Status Gizi Balita di Wilayah Kerja Puskesmas Yogyakarta. Kesehat Masy [Internet]. 2014;4(2). Available from: http://download.portalgaruda.org/article.php?article

22. Syifa Vaozia N. Faktor Risiko Kejadian Stunting Pada Anak Usia 1-3 Tahun DI Desa Menduran Kecamatan Brati Kabupaten Grobogan. J Nutr Coll. 2016;5(4):314-20.

23. Diafrilia I.M, Basuki A MN. Determinan Stunting Pada Anak Umur 24-59 Bulan di Wilayah Kerja Puskesmas Ranomuut Kecamatan Paldua. Fak Kesehat Masy Univ Sam Ratulangi Manad. 2014;

24. Swathma D, Lestari H, Teguh R. Analisis Faktor Risiko BBLR, Panjang Badan Bayi Saat Lahir dan Riwayat Imunisasi Dasar Terhadap Kejadian Stunting Pada Balita Usia 12-36 Bulan di Wilayah Kerja Puskesmas Kandai Kota Kendari. 2016;1-10.

25. Supariasa, Bakri.B \& Fajar I. Penilaian Status Gizi. Jakarta: EGC; 2012.

26. Bening S, Margawati A RA. Konsumsi Gizi Makro dan Mikro sebagai Faktor Risiko Stunting Anak Usia 2-5 Tahun di Semarang. Medica Hosp. 2016;4(1):45-50.

27. Rukmana E, Briawan D, Ekayanti I, Masyarakat DG, Manusia FE, Bogor IP. Faktor Risiko Stunting Pada Anak Usia 6-24 Bulan di Kota Bogor. MKMI. 2016;2:192-9.

28. Devy Aulia Juniar, Dina Rahayuning P MZR. Faktor-Faktor Yang Berhubungan Dengan Status Gizi Bayi Usia 0-6 Bulan di Wilayah Kerja Puskesmas Gebang, Kecamatan Gebang, Kabupaten Purworejo. Kesehat Masy [Internet]. 2019;7(1):289-96. Available from: http://ejournal3.undip.ac.id/index.php/jkm

29. Addo P, Aryeh D, Stein P, Caroline H, Fall D et al. Maternal Height and Child Growth Patterns. J Pediatr. 2013;163.

30. Zilda, Oktarina T\& S. Faktor Risiko Stunting Pada Balita (24-59 Bulan) Di Sumatera. Gizi dan Pangan. 2013;8.

31. Black RE, Allen LH, Bhutta ZA, Caulfield LE, de Onis M, Ezzati M MC\& R. maternal and child undernutrition. Glob Reg Expo Heal consequences. $2008 ; 371$.

32. Setiawan, Anggi, Nur Indrawaty Lipoeto AZI. Hubungan kadar hemoglobin ibu hamil trimester III dengan berat lahir bayi di Kota Pariaman. J FK Unand. 2014;2:34. 